suspicious of all of the physical sciences."

"We're faced with a kind of hysteria," he adds, contrasting the problems at this year's physicists' meeting in Atlanta with the last such meeting in the United States in 1987, when Ronald Reagan was president, and scientists from all countries were welcomed.

Scientists from countries labelled as 'hostile' who are already working in the United States have also felt the fallout from the Los Alamos case. However, they stress that it is the public mood, rather than the attitude of their scientific colleagues or managers, that worries them most.

"We would like to express our deep concern regarding the deterioration of the working environment of Chinese-American scientists and the scientific exchanges between the United States and China," says a letter from Cheuk-Yin Wong, chairman of the 450-strong Overseas Chinese Physics Association, to APS president Jerome Friedman. The letter followed a discussion of 150 association members at the APS meeting in Atlanta and asks Friedman for a public statement of support for Chinese-American scientists.

Wong, a nuclear theorist at the Oak Ridge National Laboratory in Tennessee, is particularly concerned by media coverage of the Los Alamos incident. He cites an article in the 22 March issue of Newsweek, which described what it termed China's "vacuum cleaner strategy" for using Chinese scientists in the United States for espionage. "There are statements in that article that will lead the general public to question the loyalty of Chinese-American scientists," Wong says.

Some press coverage has also suggested that many Chinese scientists are in the United States because the Chinese communist government wants them to take secrets back home. In fact, China has become the biggest single source of scientific immigration to the United States largely because the US Congress passed legislation in 1992 giving Chinese students special rights to stay after the crackdown against student demonstrations in Tiananmen Square.

Wong says that for Chinese-American scientists at the nuclear weapons laboratories "the environment is very nervous". But at other government laboratories, and at universities where most Chinese-American scientists work, this recent spate of China-bashing may have little effect.

"I have plenty of good things to say about the system here," says a successful Chinese-born chemist at one civilian Department of Energy laboratory. He notes that he "can't imagine the Chinese government doing the same" and allowing foreign scientists into its laboratories and universities. "It is true that people of my background have to work harder [than US-born colleagues], but I don't think that is necessarily unfair."

ColinMacilwain

\title{
Japanese researcher faces US charges over data
}

[TOKYO] The difference between Japan and the United States in their attitude towards intellectual property rights was highlighted last week when a Japanese researcher was accused of removing research data from a laboratory without proper authorization.

Yoichi Ito, a physician who was completing a research fellowship at the Mayo Clinic in Rochester, Minnesota, was charged with stealing research material three days before he was due to return to Japan.

$\mathrm{He}$ is accused of removing his research notes and materials from the clinic, as well as downloading research data from the clinic's computer going back to 1990 .

Ito, who had been working on gene sequencing in the clinic's cartilage and connective-tissue laboratory, told the US magistrate in St Paul, Minnesota, that he "did not understand what was happening", according to a report by the Associated Press.

But the Mayo clinic says he was warned on his arrival that the clinic held the rights to his research work, and that he would be required to return all materials produced during his term when he left.

Jesse Bradley, a spokesman for the clinic, says that all the regulations had been specified in Ito's contract. "We are just trying our best to get our research data back," he says.

Although US institutions can impose stringent rules on the protection of such data, Japan has no regulations covering the rights to a researcher's work outside the framework of standard patent and copyright laws.

"There are no legal requirements for researchers to return their research documents when they leave an institution," says Yoshio Namba, of the intellectual property division of the Japan Science and Technology Corporation, a semi-governmental organization that runs a fellowship programme for overseas researchers to work in Japanese laboratories. "Such requirements are not included in the contract for overseas researchers either."

"Research institutions do not have legal control over the researchers' documents unless they are particular types of computer programs, with strict regulations on copyrights," says Hiroko Saito, who is responsible for intellectual property rights issues at the Institute of Physical and Chemical Research.

Some scientists say that the different legal structure and general 'culture' of Japanese labs compared with those elsewhere could pose serious threats to collaborative research and exchange programmes. AsakoSaegusa

\section{Ethical failures block Los Angeles research}

[SAN DIEGo] An interim research management team was sent last week from Washington to direct future research efforts at the troubled veterans' hospital system in Los Angeles, where all research has been suspended by federal officials who are concerned about failures to correct long-running deficiencies in compliance with federal ethics rules.

The identified deficiencies were restricted to the sprawling West Los Angeles Veterans' Affairs (VA) Healthcare Center. But they caused federal officials to shut down human and animal research at all VA facilities throughout the Los Angeles region.

Up to 1,200 research projects could be affected, according to VA officials. No patients can be enrolled in a research project and no new protocol can start until scientists and administrators can document that all federal requirements will be met. Only studies in which the lives of patients or animals are at risk can continue, said officials.

Troubling questions about scientific practices at the West Los Angeles VA Healthcare Center - the largest of the VA hospitals have been raised by the breadth of problems with the studies, the apparent lack of knowledge of senior federal officials about some unethical practices, and inadequate responses from management to years of administrative deficiencies.

Kenneth W. Kizer, the VA under-secretary for health in Washington DC, suspended all VA research in Los Angeles from $26 \mathrm{March}$, four days after the National Institutes of Health's Office for Protection from Research Risks suspended the assurance agreement under which VA scientists in Los Angeles conducted federally funded human studies.

In his letter suspending human and animal studies, Kizer wrote: "The lack of adherence to research policy and operational requirements is a very grave matter. Regrettably, facility management's unresponsiveness now adversely affects individual investigators."

VA officials in Los Angeles responded by replacing the acting director of research, appointing new chairmen to the human institutional review boards and animal review committees, and reassessing all committee membership. 